\title{
ONTOGÊNESE DAS FUNÇÕES COGNITIVAS: UMA ABORDAGEM NEUROPSICOLÓGICA
}

Emmy Uehara Pires

O presente estudo teve como objetivo compreender como se dá a ontogênese das funçôes cognitivas no período entre o nascimento até a adolescência. A partir da perspectiva da neuropsicologia cognitiva, questôes como a maturação cerebral, bases neuroanatômicas, avaliação neuropsicológica são observadas ao longo dos capítulos. Por fim, a ênfase é dada aos marcos mais relevantes no processo típico do desenvolvimento das principais funçôes cognitivas.

\section{BANCA:}

Jesus Landeira Fernandez (Orientador)

Helenice Charchat Fichman

Rosinda Martins Oliveira

Data de defesa: 22/02/2010 